\title{
Ecological Observations, Preliminary Checklist and Conservation of Mammals Occurring Within the Eastern Boundaries of Ethiope River, Niger Delta Area of Nigeria
}

\author{
Francis O. Arimoro ${ }^{1^{*}}$, Edike A. Kaine ${ }^{2}$, Blessing O. Krumale ${ }^{1,3}$ and Smart Obiegba ${ }^{3}$ \\ ${ }^{1}$ Department of Biological Sciences, Federal University of Technology, P.M.B. 65, Minna, Nigeria \\ ${ }^{2}$ Environmental Assessment Unit, Fugro Nigeria Limited, 91 Odani Road (Fugro Avenue), Off PH - Eleme Expressway, Elelenwo, P. M. B. 053 Port Harcourt, Nigeria \\ ${ }^{3}$ Department of Animal and Environmental biology Delta State University, P.M.B. 1, Abraka, Nigeria
}

${ }^{*}$ Corresponding author: Francis O. Arimoro, Department of Biological Sciences, Federal University of Technology, P.M.B. 65, Minna, Nigeria, Tel: +2348035615424; Email: fransarimoro@yahoo.com

Received date: Mar 31, 2014, Accepted date: Apr 28, 2014, Publication date: May 05, 2014

Copyright: @ 2014 Arimoro FO, et al. This is an open-access article distributed under the terms of the Creative Commons Attribution License, which permits unrestricted use, distribution, and reproduction in any medium, provided the original author and source are credited.

\begin{abstract}
This study examined the ecological distribution and abundance of mammals in the eastern Ethiope ecoregion of the Niger Delta area at three designated survey blocks over a period of six months. Mammals were surveyed by observing their habitat nests, burrows, faecal pellets, captured samples from hunters' handbags and bush meat sales from men in the mapped out area. Survey block I was located at a commercial demanding area while survey block II and III were located southwards the commercial impacted area. Results of the ecological observations and checklists showed that the relative diversity and abundance of mammal species were significantly different $(p<0.05)$ among the survey blocks mapped out. The vegetation cover, rate of habitat loss and hunting activities were different amongst the survey blocks examined. A total of twenty four species of mammals were identified with Cricetomys gambianus, the giant rat being the most abundant species followed by Cephalophus maxwelli the Maxwells Duiker, while Manis tricuspis, the White bellied Pangolin was only seldom observed. Conservation of this important habitat is recommended for sustainability and benefit to the local people.
\end{abstract}

Keywords: Mammals; Ecology; Maxwell duiker; Ethiope river; Ecotone; Niger delta

\section{Introduction}

Nigeria is the third most biologically diverse African country in terms of both plant and animal species distribution. In spite of this important status, the environment is presently exposed to forest species loss and decimation as a result of anthropogenic perturbations resulting from urbanization, agriculture, deforestation, industrialization and other sundry activities [1-3]. There is little information available concerning most of the mammals of Nigeria in terms of ecology, diversity and abundance [4-7]. In particular, the knowledge of mammals around the Niger Delta is still fragmentary due to the different levels of exploration of the various areas of the Delta.

Over-harvesting of forest products and wildlife is closely facilitated by ignorance on the part of the resource users, weak resource tenure systems including ineffective and non-enforcement of policies on the part of the government, when the most seriously affected resources in this regard is wildlife. The "bush meat" trade provides a significant source of income for rural forest fringe populations and represents almost $80 \%$ of their animal protein intake. Over-harvesting and use of unsustainable harvesting methods is almost inevitable. The commercialization of bush meat is probably a more significant and immediate threat than forest loss for the majority of primates as well as for many other mammals [8]. Despite those incessant human exploitations and disturbances, the need for biodiversity conservation was realized in Nigeria as far back as 1946 when some strict nature reserves and forest reserves were established. After independence, further reviews of the ordinances were made by the regional government, but they were still inadequate [9]. Early conservation trends in Nigeria were certain taboos and traditional customs which prevented the killing or hunting of certain animals for food; a notable example is the mona monkey in most southern parts of Nigeria. In a number of such communities, small sections of forests still contain endangered species of monkeys and other mammals protected because of the importance placed by the local people [10-12].

Following the fast declining state of the nation's wildlife and the need for effective conservation measures to be put in place to check the depletion and extinction of mammalian species, this research work was undertaken to:

(1) Serve as a basis to ascertain the abundance of various mammals in Ethiope River ecoregion

(2) assess the current status and threats to the population of mammals in this geographical area with a view to providing conservation and remediation measures to safeguard the over exploitation of existing wildlife populations within this geographical area.

\section{Study Area}

\section{The Ethiope forest ecoregion}

The Ethiope forest ecoregion falls within the tropical rainforest zone of southern Nigeria. It is located just behind the channel flows of the Ethiope River which takes its source from Umuaja, down to its 
Citation: $\quad$ Arimoro FO, Kaine EA, Krumale BO, Obiegba S (2014) Ecological Observations, Preliminary Checklist and Conservation of Mammals Occurring Within the Eastern Boundaries of Ethiope River, Niger Delta Area of Nigeria. J Biodivers Biopros Dev 1: 104. doi:10.4172/ 2376-0214.1000104

Page 2 of 10

mouth at Sapele both located within Delta State, Nigeria [12], between (50 51'.00" N; 6. 09. 00" E) Ukwuani Local Government Area and Eku ( 50 45' 25" N; 60 03. 20") Ethiope East Local Government Area, both located in Delta State, Nigeria (Figure 1).

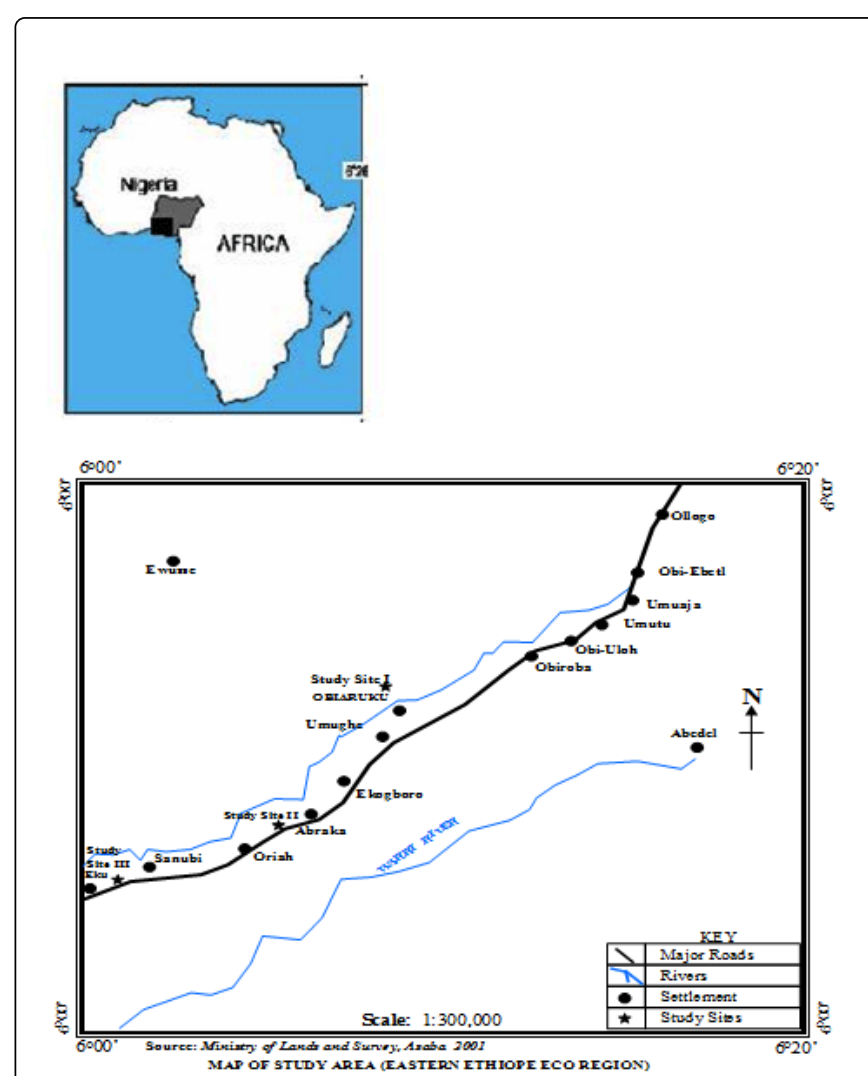

Figure 1: Map of study area showing the eastern boundaries of the Ethiope River with the three survey blocks.

\section{Climate}

The climate of this ecoregion is typical of the seasonal variations of the Northern trade wind from the Sahara and the Southwest trade wind from the Atlantic, bringing about the rainy and dry seasons. The rainy season begins in April and lasts till October, and a brief dry season commence from November to March. The wet season peaks in July. A marked interruption in the rains occurs during August resulting in a short dry season often referred to as the "August break." Precipitation is heavier in this area which receives more than 120 inches $(3,000 \mathrm{~mm})$ of rain a year. Relative humidity is usually above $57 \%$ and fluctuates between $70-80 \%$ for most of the year. The average daily temperature is $27^{\circ} \mathrm{C}$.

\section{Vegetation}

The vegetation of the area is that of a lowland rainforest with sandyloam soil which supports different plant forms especially, the trees and shrubs. The forest is usually characterized by a three strata arrangement. Emergent trees include the popular and common Iroko (Chlorophora excelsa), Rubber tree (Hevea braziliensis), Obeche (Triplochiton scleroxylon), Mahogany (Khaya ivorensis). The middle strata include trees such as the oil palm (Elaeis guinensis) and Raffia palm (Raffia hookeri). The lower trees include the bush mango (Irvingia gabonensis) etc. The herb layer is formed from herbacecus plants, shrubs and tree seedling. A wide range of life forms, including many epiphytic forms and orchids, are present in the Ethiope forest ecoregion and grasses are rare. Tree height ranges from 18 to $23 \mathrm{~m}$. This is relatively low for a rainforest however emergent trees of heights between 31 and $36 \mathrm{~m}$ occur at low densities. Grasses are rarely predominant around the study area where human activity is minimal.

\section{Human community}

The area is inhabited by the Ukwuani speaking people of Obiaruku and the Urhobo speaking people of Abraka and Eku rural settlements respectively. The inhabitants are predominantly farmers and cultivate crops such as cassava (Manihot sp), Plantain (Musa sapienta), Melon (Colocynthys vulgaris), Yam (Dioscorea sp), Corn (Zea mays), Okra (Abelmeschus esculentus), other occupations include hunting, fishing, weaving, trading and sculpture making.

\section{Materials and Methods}

\section{Sampling procedure}

Following the necessity to obtain reliable ecological information of the mammalian diversity within this area, we embarked on a sixmonth surveillance study lasting from February to July 2009. Procedures employed included host community consultation in addition to a simplified sweep survey of the area. The Ethiope Eastern boundaries were divided into three survey blocks; I - North (Obiaruku) (Plate 1) II Central (Abraka), III - South (Eku) (Plate 2). Contact visit expeditions were carried out including interviews with experienced, retired hunters as well as village heads. Bush meat markets were visited as well as contacts with sales men. In this way, vital information on both past and present ecological and population fauna status in the area was assessed.

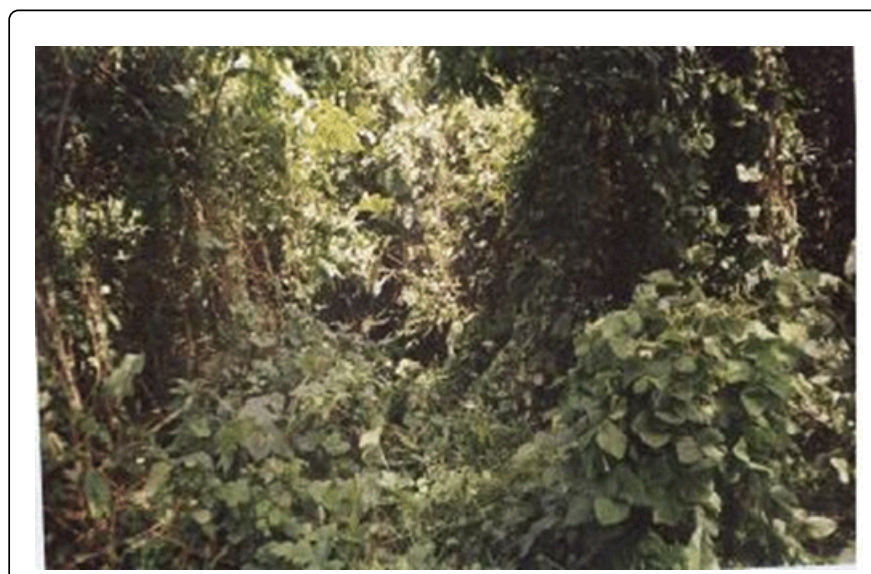

Plate 1: An undisturbed section of the study area (most large mammals inhabit this section BlockI).

A pair of binoculars was employed for the sighting of tree squirrels and other arboreal animals as well as the nests of arboreal mammals at the uppermost branches. A digital camera was used to take snapshots of the mammals captured in the live traps and those in the hunter's bags. Hand gloves were worn when handling the animals and traps. A helmet was worn in the field for protection against falls as well as 
Citation: Arimoro FO, Kaine EA, Krumale BO, Obiegba S (2014) Ecological Observations, Preliminary Checklist and Conservation of Mammals Occurring Within the Eastern Boundaries of Ethiope River, Niger Delta Area of Nigeria. J Biodivers Biopros Dev 1: 104. doi:10.4172/ 2376-0214.1000104

Page 3 of 10

protective clothing worn to protect the skin against thorns, scratches and bites of the thick forest. A compass was employed for location specificity. The animals were identified using a field guide of African mammals by Booth [13], De Blase and Martin [14] and Theodore and Helmut [15].

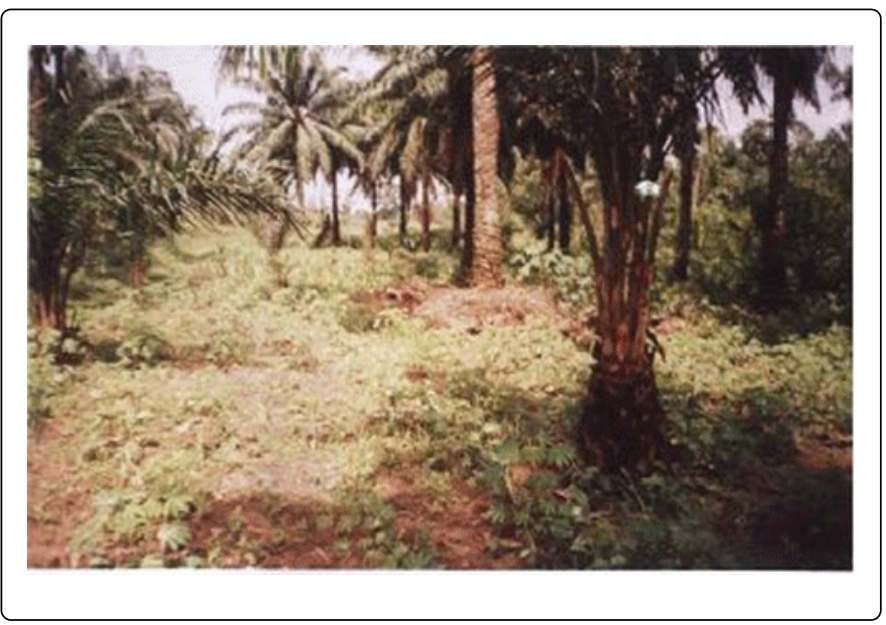

Plate 2: A section of survey block II disturbed by farming activities.

The animals were captured using the live traps which were set by the local hunters. The traps were baited with foods such as palm fruits, cassava and other fruits to attract them. The traps were of various forms and types depending on the animal behaviour and ecology. Burrowing animals like the Giant Rat, Cricetomys gambianus and the Giant ground squirrel, Xerus erythropus were caught with burrow traps. The barrier trap was used for trapping animals like the Maxwell's Duiker, Cephalophus maxwelli. The various trapping methods were useful for capturing animals and thereafter released back into the wild. Field work and sampling was carried out thrice in a month. Besides trapping of animals, other methods were also employed such as the direct sighting for highly sensitive mammals like the flying squirrels and the long nosed mongoose. The presence of feeding spots, foot prints, nests and droppings were also employed in identification. Other mammals were identified with the aid of a hunter through the specific call alerts (sounds and vocalization) either for danger or mating.

Hunters' bags and specimens usually sold at bush meat markets were also examined and photographs taken (Plate 3, 4 and 5). From the hunting records and consultation of association and groups in the area, a total of 83 hunters are currently operating in the area. Information on hunters association in the area was very important so as to be certain if there are any traditional conservation measures currently being put in place. This also gave an insight of the hunting pressure in the area.

All population counts were done by indirect assessments as it is often impossible to obtain accurate, visual or auditory counts of the animals in a population, hence in this study, we used indirect signs of the animals present as indices of relative abundance. Sample counts were made, and the results extrapolated to other areas of similar vegetation type within the survey block. The standard King's Strip Census (KSC) was employed.

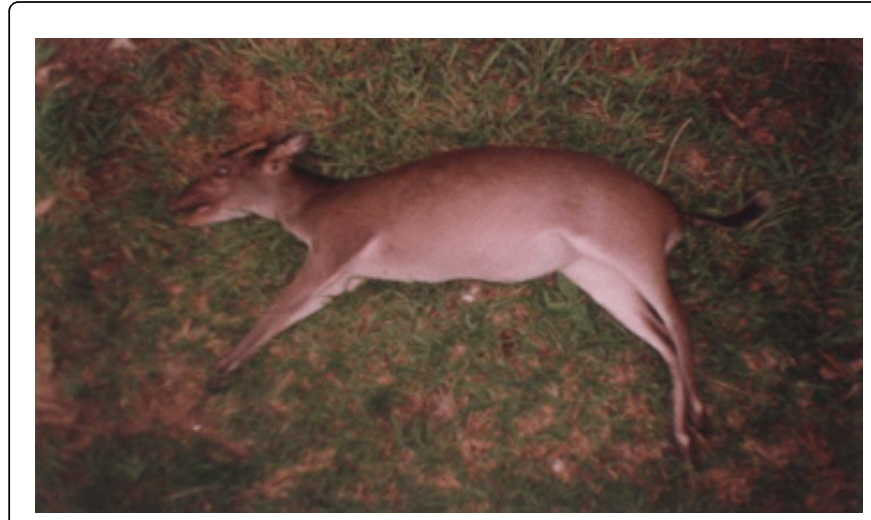

Plate 3: Maxwell's Duiker Cephalophus maxwelli photographed from hunters bag.

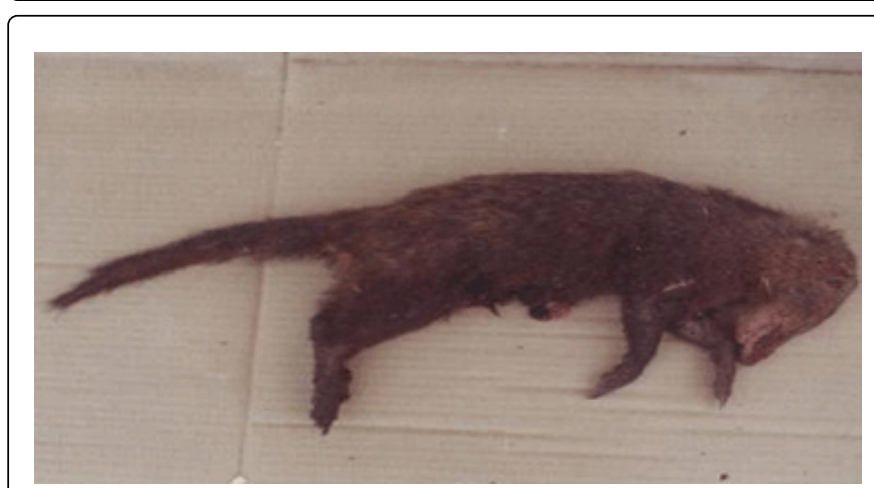

Plate 4: A Cusimanse mongoose Crossarchus obscurus from the hunters bag, shot by a hunters gun.

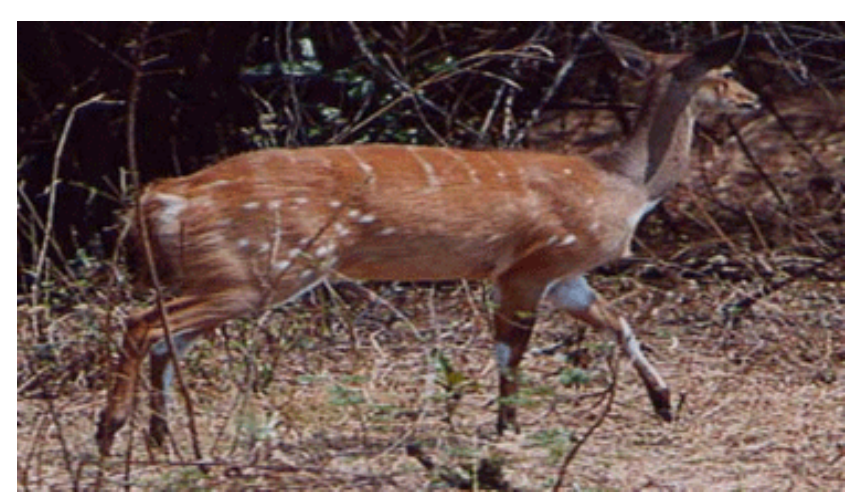

Plate 5: Bush buck Tragelaphus scriptus (sighted in the study area).

\section{Kings Strip Census (KSC)}

This method involves making systematic or random transects within the sample area. The observer makes left and right observations, up to a sighting distance of about 100 metres, in the dense tropical rain forest. Records are kept for each tract as follows:

- Length of Transect 
Citation: Arimoro FO, Kaine EA, Krumale BO, Obiegba S (2014) Ecological Observations, Preliminary Checklist and Conservation of Mammals Occurring Within the Eastern Boundaries of Ethiope River, Niger Delta Area of Nigeria. J Biodivers Biopros Dev 1: 104. doi:10.4172/ 2376-0214.1000104

Page 4 of 10

- Number of animals seen for a particular species

- Average sighting distance, perpendicular to the transect line

- Total area covered by the observer's efforts.

The formula for calculating the population of each species of animals for the area covered is as

follows:

$\mathrm{P}=\mathrm{AZi}$

XiYi

Where

$\mathrm{P}=$ Total population of a particular species of animal

$\mathrm{Xi}=$ Average sighting distance of animals perpendicular to transect line $\mathrm{i}$

$\mathrm{Yi}=$ Length of transect line $\mathrm{i}$

$\mathrm{Zi}=$ Number of animals seen along transect line $\mathrm{i}$

$\mathrm{A}=$ Total area

$2 \mathrm{XiYi}=$ Total area sampled for transect line $\mathrm{i}$

The calculation is then repeated for all species of animals. Densities of mammals were treated separately for each block consisting of different vegetation types. The extrapolated density for a given species occurring in a block was thus estimated. In all a total of eighteen separate survey were made during the period and the average taken.

Taxa richness (Margalef index), diversity (Shannon, \& Simpson dominance indices) and evenness indices were calculated using the computer BASIC programme SP DIVERS [16].

\section{Results}

During the period of study, a total of twenty four (24) species of mammals were identified from all the sampling techniques put together (Table 1). The current status of their habitats were observed to be heavily degraded due to agricultural activities such as cultivation of crops which has led to land fragmentation, bush burning, erosion, falling down of trees for timber by the village occupants. This has resulted to degradation of most habitats and rendered most fauna population homeless as opposed to an undisturbed section of the study area were most large mammals inhabit.

The evidence of the relative abundance of traps, faecal pellets and footprints were more frequently detected and observed than the direct sightings of the animals themselves. Table 1 shows the mammals observed, their relative habitats, mode of identification and their IUCN status.

\begin{tabular}{|c|c|c|c|c|c|c|}
\hline \multirow[b]{2}{*}{ Common Name } & \multirow[b]{2}{*}{ Species } & \multirow[b]{2}{*}{ IUCN Category } & \multirow[b]{2}{*}{ Mode of Identification } & \multicolumn{3}{|c|}{ Vegetation/Habitat } \\
\hline & & & & Forest & Farm-bush & Grass land \\
\hline Grasscutter & Thryonomys swinderianus & LC & $\mathrm{HB}, \mathrm{FS}$ & $\checkmark$ & $\sqrt{ }$ & $\sqrt{ }$ \\
\hline Bush tailed porcupine & Atherurus africanus & LC & $\mathrm{HB}, \mathrm{FP}$ & $\checkmark$ & $\sqrt{ }$ & - \\
\hline Giant Pouched rat & Cricetomys gambianus & LC & $\mathrm{HB}, \mathrm{BH}, \mathrm{DS}$ & - & $\sqrt{ }$ & $\sqrt{ }$ \\
\hline Ground squirrel & Xerus erythropus & LC & $\mathrm{BH}, \mathrm{DS}$ & - & $\sqrt{ }$ & $\sqrt{ }$ \\
\hline Orange headed squirrel & Funisciurus olivae & DD & DS, HB & $\sqrt{ }$ & $\sqrt{ }$ & - \\
\hline Beecrofts flying squirrel & Anomalurops beecrofti & LC & $\mathrm{FP}$ & $\sqrt{ }$ & - & - \\
\hline Nigerian musk shrew & Crocidura nigeriae & LC & DS & - & $\sqrt{ }$ & $\sqrt{ }$ \\
\hline Spotted grass mouse & Lemniscomys striatus & LC & DS, FT & - & $\sqrt{ }$ & $\sqrt{ }$ \\
\hline House Rat & Rattus rattus & LC & DS & - & $\sqrt{ }$ & $\sqrt{ }$ \\
\hline Pygmy Mouse & Mus musculus & LC & DS, BH & - & $\sqrt{ }$ & $\sqrt{ }$ \\
\hline Bosmans potto & Perodicticus potto & LC & $\mathrm{NH}, \mathrm{HB}$ & $\sqrt{ }$ & $\sqrt{ }$ & - \\
\hline Lesser bush baby & Galagoides demidovii & LC & $\mathrm{NH}$ & $\sqrt{ }$ & - & - \\
\hline White bellied Pangolin & Manis tricuspis & LC & FS & $\sqrt{ }$ & $\sqrt{ }$ & - \\
\hline African civet & Viverra civetta & NT & $\mathrm{HB}, \mathrm{FP}$ & $\sqrt{ }$ & $\sqrt{ }$ & $\sqrt{ }$ \\
\hline \multirow[t]{2}{*}{ Forest genet } & Genetta poensis & LC & $H B$ & $\sqrt{ }$ & $\sqrt{ }$ & - \\
\hline & & & & \multicolumn{3}{|c|}{ Vegetation/Habitat } \\
\hline Common Name & Species & IUCN Category & Mode of Identification & Forest & Farm-bush & Grass land \\
\hline Cuisimanse mongoose & Crossarchus obscures & LC & $\mathrm{HB}, \mathrm{FS}, \mathrm{DS}$ & $\sqrt{ }$ & $\sqrt{ }$ & - \\
\hline Dwarf mongoose & Herpestes sanguinensis & DD & $H B$ & $\sqrt{ }$ & $\sqrt{ }$ & - \\
\hline
\end{tabular}


Citation: $\quad$ Arimoro FO, Kaine EA, Krumale BO, Obiegba S (2014) Ecological Observations, Preliminary Checklist and Conservation of Mammals Occurring Within the Eastern Boundaries of Ethiope River, Niger Delta Area of Nigeria. J Biodivers Biopros Dev 1: 104. doi:10.4172/ 2376-0214.1000104

\begin{tabular}{|l|l|l|l|l|l|l|}
\hline Bush Buck & Tragelaphus scriptus & LC & HB, FP & $\sqrt{ }$ & $\sqrt{ }$ & $\sqrt{ }$ \\
\hline Maxwell's Duiker & Cephalophus maxwelli & NT & HB, DS & - & $\sqrt{ }$ & $\sqrt{ }$ \\
\hline Bush Pig (Hog) & Potamochoerus porcus & LC & HB & $\sqrt{ }$ & - \\
\hline Straw Coloured fruit bat & Eidolon helvum & LC & DS & $\sqrt{ }$ & $\sqrt{ }$ & - \\
\hline Nigerian lesser free tailed bat & Tadarida nigeriae & LC & DS & $\sqrt{ }$ & $\sqrt{ }$ \\
\hline Franquets fruit bat & Epomops franqueti & LC & DS, HB & $\sqrt{ }$ & $\sqrt{ }$ \\
\hline Pipistrellus & Pipistrellus pipstrellus & LC & DS, HB & $\sqrt{ }$ & $\sqrt{ }$ \\
\hline
\end{tabular}

Table 1: Associated Habitat/Vegetations of Mammal Species and IUCN Red List Status Categories and Mode of Identification.

The following tags are used to highlight each species conservation status as assessed by the IUCN red list (2000)[17]:

EN - Endangered; the species is facing an extremely high risk of extinction in the wild.

VU - Vulnerable; the species is facing a high risk of extinction in the Wild.

NT -Near Threatened; the species does not meet any of the criteria that would categorize it as risking extinction but it is likely to do so in future.

LC - Least Concern; There are no current identifiable risks to the species.

DD - Data Deficient; There is inadequate information to make an assessment of the risks to this species.

\section{Mode of Identification Key}

DS- Direct sighting, HB -Hunters bag, FS-Feeding spot, FP-Faecal pellet, FT-Footprints NH-Nest Habitat,

BH- Burrow habitat. IUCN Species Survival Commission (2000)

Table 2 shows the estimated population of mammals in the three survey blocks of the Eastern boundary of Ethiope River. Clearly, more species were recorded in the survey block II as compared with the other survey blocks. The Giant Pouched rat, Cricetomys gambianus was the most abundant species followed by the Maxwell's Duiker, Cephalophus maxwelli. These species were not sighted in survey block I. The richness and diversity indices showed that survey block I and II were richer than III, however the population estimate showed that Survey block II was the richest followed by survey block III and I in that order (Table 3).

\begin{tabular}{|c|c|c|c|c|}
\hline Common Name & Species & Survey block I & $\begin{array}{l}\text { Survey block } \\
\text { II }\end{array}$ & Survey block III \\
\hline Grasscutter & Thryonomys swinderianus & 250 & 430 & 680 \\
\hline Bush tailed porcupine & Atherurus africanus & 140 & 520 & - \\
\hline Giant Pouched rat & Cricetomys gambianus & - & 780 & 2600 \\
\hline Ground squirrel & Xerus erythropus & - & 340 & 240 \\
\hline Orange headed squirrel & Funisciurus olivae & 30 & 140 & - \\
\hline Beecrofts flying squirrel & Anomalurops beecrofti & 70 & - & - \\
\hline Nigerian musk shrew & Crocidura nigeriae & - & 180 & 260 \\
\hline Spotted grass mouse & Lemniscomys striatus & - & 160 & 160 \\
\hline House Rat & Rattus rattus & - & 80 & 350 \\
\hline Pygmy Mouse & Mus musculus & - & 60 & 470 \\
\hline Bosmans potto & Perodicticus potto & 160 & 140 & - \\
\hline Lesser bush baby & Galagoides demidovii & 190 & - & - \\
\hline White bellied Pangolin & Manis tricuspis & 10 & 20 & - \\
\hline African civet & Viverra civetta & 260 & 240 & 830 \\
\hline Forest genet & Genetta poensis & 190 & 140 & - \\
\hline Cuisimanse mongoose & Crossarchus obscurus & 170 & 260 & - \\
\hline
\end{tabular}


Citation: Arimoro FO, Kaine EA, Krumale BO, Obiegba S (2014) Ecological Observations, Preliminary Checklist and Conservation of Mammals Occurring Within the Eastern Boundaries of Ethiope River, Niger Delta Area of Nigeria. J Biodivers Biopros Dev 1: 104. doi:10.4172/ 2376-0214.1000104

Page 6 of 10

\begin{tabular}{|l|l|l|l|l|}
\hline Dwarf mongoose & Herpestes sanguinensis & 60 & 240 & - \\
\hline Bush Buck & Tragelaphus scriptus & 40 & 80 & 40 \\
\hline Maxwell's Duiker & Cephalophus maxwelli & - & 620 & 1280 \\
\hline Bush Pig (Hog) & Potamochoerus porcus & 40 & 20 & - \\
\hline Straw Coloured fruit bat & Eidolon helvum & 560 & 420 & - \\
\hline Nigerian lesser free tailed bat & Tadarida nigeriae & 470 & 120 & - \\
\hline Franquets fruit bat & Epomops franqueti & 340 & 160 & - \\
\hline Pipistrellus & Pipistrellus pipstrellus & 260 & 120 & - \\
\hline
\end{tabular}

Table 2: Estimated population of mammals at the three survey block.

\begin{tabular}{|l|l|l|l|}
\hline & Survey Block 1 & Survey Block II & Survey Block III \\
\hline Species No. & 17 & 22 & 10 \\
\hline Estimated population & 3240 & 7350 & 4830 \\
\hline SPECIES RICHNESS INDICES & & & \\
\hline Margalef's index(d): & 1.979 & 2.359 & 1.061 \\
\hline DIVERSITY INDICES & & & 2.750 \\
\hline Shannon-diversity & 2.521 & 2.416 & 0.758 \\
\hline Index (H'): & 1.095 & 1.049 & 0.94 \\
\hline Shannon and Wiener Index (H): & & & 0.293 \\
\hline Evenness Index(E'): & 0.89 & 0.782 & 0.159 \\
\hline Simpson's Dominance Index (C): & 0.096 & & \\
\hline
\end{tabular}

Table 3: Species Richness and Diversity indices of mammalian population in the three survey blocks of Ethiope River ecotone.

In the course of this research, it was also observed that majority of the animals were used for bush meat (protein) than for any other purpose, such as aesthetic values, medicinal, concoctive or for use as pets or domestication. The local hunters and village heads provided information on the hunting pressure of the animals and the various trapping methods used (Table 4).

\begin{tabular}{|l|l|l|l|l|}
\hline & Family & Species & Common name & Ecological notes \\
\hline RODENTIA & Thryonomidae & $\begin{array}{l}\text { Thryonomys } \\
\text { swinderianus }\end{array}$ & Grasscutter & $\begin{array}{l}\text { Rounded, heavy, large head. Tail short, legs short and } \\
\text { sturdy. Incisors very wide and powerful. Hair rough, } \\
\text { bristly. Almost active during the day and night. Feeds on } \\
\text { roots, shoots, grasses and nuts. }\end{array}$ \\
\cline { 2 - 5 } & Hystricidae & Atherurus africanus & Brush tailed porcupine & $\begin{array}{l}\text { Slender body, forehead swollen, eyes small. Legs short } \\
\text { and sturdy. Upper side of body greyish brown to } \\
\text { brownish black. Tail ends in a brush like ending. Body } \\
\text { possesses less conspicuous spines. }\end{array}$ \\
\cline { 2 - 5 } & Cricetidae & Cricetomys gambrianus & $\begin{array}{l}\text { Rat-like in form, but large. Has a long tail with a whitish } \\
\text { ending and longer than body. Hind feet wholly or partly } \\
\text { white. Jumps and climbs well. Eats fruits (palm) } \\
\text { nocturnal but sometimes out by day. Large check } \\
\text { pouches, small eyes. }\end{array}$ \\
\cline { 2 - 5 } & Sciuridae & Xerus erythropus & Ground squirrel & $\begin{array}{l}\text { Large squirrel. It is sandy in colour with a white side } \\
\text { stripe. Lives on the ground. It is diurnal and a burrower. } \\
\text { Eats roots and also takes fallen fruits. }\end{array}$ \\
\hline
\end{tabular}


Citation: Arimoro FO, Kaine EA, Krumale BO, Obiegba S (2014) Ecological Observations, Preliminary Checklist and Conservation of Mammals Occurring Within the Eastern Boundaries of Ethiope River, Niger Delta Area of Nigeria. J Biodivers Biopros Dev 1: 104. doi:10.4172/ 2376-0214.1000104

\begin{tabular}{|c|c|c|c|c|}
\hline & Sciuridae & Funisciurus olivae & $\begin{array}{l}\text { Orange } \quad \text { headed } \\
\text { squirrel. }\end{array}$ & $\begin{array}{l}\text { A little bit large with a very long tail. It has an orange } \\
\text { head and some spots of row on the side. }\end{array}$ \\
\hline & Sciuridae & Anomalurops beecrofti & $\begin{array}{l}\text { Beecrofts flying } \\
\text { squirrel. }\end{array}$ & $\begin{array}{l}\text { Has a beautiful orange throat and chest. Lives in small } \\
\text { parties. Eats fruits and leaves. }\end{array}$ \\
\hline & Family & Species & Common name & Ecological notes \\
\hline & Muridae & Lemniscomys striatus & Spotted grass mouse. & $\begin{array}{l}\text { It is a pretty mouse. It is stripped longitudinally on a dark } \\
\text { brown back ground. The stripes are a series of spots. It } \\
\text { is diurnal, seed eating and lives in burrows and crevices. }\end{array}$ \\
\hline & Muridae & Mus musculus & Pygmy mouse & $\begin{array}{l}\text { They are very small. They can live almost anywhere in } \\
\text { holes and thick vegetations even in houses. Eats insects } \\
\text { and vegetable. }\end{array}$ \\
\hline RODENTIA & Muridae & Rattus rattus & House rat. & $\begin{array}{l}\text { This is very dark-grey. It is a good climber and runner } \\
\text { and eats virtually anything it can over power. It is } \\
\text { common in our homes and surroundings. }\end{array}$ \\
\hline INSECTIVORA & Soricidae & Crocidura nigeriae & Nigerian Musk shrew & $\begin{array}{l}\text { It is insectivorous. Makes a squealing noise. Has a } \\
\text { heavy sweet smell. This is partly a defense mechanism. } \\
\text { They are nocturnal and very secretive in habit. }\end{array}$ \\
\hline PHOLIDOTA & Manidae & Manis tricuspis & White bellied pangolin & $\begin{array}{l}\text { It is naturally insectivorous, found along swamp. It is } \\
\text { nocturnal and solitary. It curls up when danger is } \\
\text { imminent. Sleeps and hides on trees and dead } \\
\text { branches. }\end{array}$ \\
\hline \multirow[t]{2}{*}{ PRIMATE } & Horisidae & Galagoides demidovii & Lesser bush baby & $\begin{array}{l}\text { Has very large conspicuous eye. It is nocturnal and } \\
\text { leads a solitary life on trees. Makes a "ti pitche" sound ti- } \\
\text { ti-ti where there is need for alert. Runs and climbs very } \\
\text { well. Sleeps during the day among dense foliage. Builds } \\
\text { nests in trees. Eats insects and some fruits. }\end{array}$ \\
\hline & Family & Species & Common name & Ecological notes \\
\hline \multirow[t]{4}{*}{ CARNIVORA } & Horisidae & Perodicticus potto & Bosmans potto & $\begin{array}{l}\text { A very slow moving lower primate. It is nocturnal. Lives } \\
\text { on trees and is a good climber. It may lead a solitary life. } \\
\text { Size of a small rat with brown wooly fur and very short } \\
\text { tail. Have large eyes. Takes insects, snail and will not } \\
\text { neglect fruits. }\end{array}$ \\
\hline & Viverridae & Genetta poensis & Forest genet & $\begin{array}{l}\text { It is an omnivorous mammal. They look like cat. It is an } \\
\text { easy runner and pounces on its prey. A good climber. It } \\
\text { is nocturnal. Has a slender body with a long tail. It is } \\
\text { boldly spotted. }\end{array}$ \\
\hline & Viverridae & Viverra civetta & African civet & $\begin{array}{l}\text { Has a handsome spotted pelt. Shuttles when hunting } \\
\text { and gobbles and gorges when eating. It is a carnivore } \\
\text { and nocturnal. As big as most local dogs but has a } \\
\text { longer body build. Have short legs in contrast to the long } \\
\text { legs of the dogs. It has a gland around the anal region } \\
\text { that produces a characteristic scent. This is practically to } \\
\text { mark territories. Eats snails, millipedes and palm fruits. }\end{array}$ \\
\hline & Viverridae & Crossarchus obscures & Cusimanse mongoose & $\begin{array}{l}\text { It is a good runner. Has a brown fur coating. Walks in } \\
\text { family groups of } 10-20 \text { members. It is active almost day } \\
\text { and night. Good climber most especially the palm trees. } \\
\text { Has a prominent long snout (nose). }\end{array}$ \\
\hline CARNIVORA & Viverridae & Herpestes sanguinensis & Dwarf mongoose & $\begin{array}{l}\text { Takes insects and some fruits. Has a ruddy colour. It is a } \\
\text { justifiable terror wherever it goes. }\end{array}$ \\
\hline \multirow[t]{3}{*}{ ARTIODACTYLA } & Family & Species & Common name & Ecological notes \\
\hline & Bovidae & Tragelaphus scriptus & Bush buck & $\begin{array}{l}\text { Walks in pairs. The male has tusks while the female is } \\
\text { not conspicuous. Runs like the antelope. Has a yellow } \\
\text { coating with white spots. }\end{array}$ \\
\hline & Bovidae & Cephaloplus maxwelli & Maxwellis duiker & $\begin{array}{l}\text { It is a good runner. Has a grey black colour. Has a short } \\
\text { tail. It eats grasses and mainly herbivorous. Have long } \\
\text { legs. }\end{array}$ \\
\hline
\end{tabular}


Citation: $\quad$ Arimoro FO, Kaine EA, Krumale BO, Obiegba S (2014) Ecological Observations, Preliminary Checklist and Conservation of Mammals Occurring Within the Eastern Boundaries of Ethiope River, Niger Delta Area of Nigeria. J Biodivers Biopros Dev 1: 104. doi:10.4172/ 2376-0214.1000104

Page 8 of 10

\begin{tabular}{|c|c|c|c|c|}
\hline ARTIODACTYLA & Suidae & Potamachoeus porcus & Bush pig (Hog) & $\begin{array}{l}\text { A medium sized mammal and has relatively short legs } \\
\text { and coarse sparse hair. They are omnivorous. It is a } \\
\text { very aggressive animal. It is active almost day and night. }\end{array}$ \\
\hline \multirow[t]{3}{*}{ CHIROPTERA } & Pteropidae & Eidolon helvum & $\begin{array}{l}\text { Straw coloured fruit } \\
\text { bat }\end{array}$ & $\begin{array}{l}\text { It is a large bat. It has a straw colour. Goes about in } \\
\text { large flocks. It feeds on fruits. They hang upside down } \\
\text { on trees. }\end{array}$ \\
\hline & & Epomops franqueti & Franquets fruit bat & This is a noisy large bat, found in the high forest. \\
\hline & Molossidae & Tadarida nigeriae & $\begin{array}{l}\text { Nigerian lesser free } \\
\text { tailed bat }\end{array}$ & $\begin{array}{l}\text { The flight membrane is short and the tail projects well } \\
\text { beyond it. Frequently occupies roofs and they are very } \\
\text { noisy. }\end{array}$ \\
\hline & Vespeltili onidae & Pipistrellus pipistrellus & Pipistrellus & $\begin{array}{l}\text { This is one of the smallest bats so far. Has a dark brown } \\
\text { coat fur. Common in thatched roots. }\end{array}$ \\
\hline
\end{tabular}

Table 4: Mammals occurring within the study area and their ecological notes.

Table 4 depicts the various mammals occurring within the study area and their ecological note. Majority of the mammals recorded were herbivores belonging to the Order Rodentia, characterized by their very sharp, wide and powerful incisors teeth. Some of them such as Crocidura nigeriae, Mus musculus also fed on insects. Most primates recorded in the study fed on a wide range of plant and animal materials (omnivores) and a few carnivores such as the african civet, Viverra civetta were also recorded.

\section{Discussion}

Comparing results from the three Survey blocks suggests that the survey block II had richer vegetation and this also translated to high numbers of mammals especially herbivores sighted at that section. A total of 24 species of mammals were reported in this study. Like other studies, a large portion of Nigeria's forest has been lost to other forms of land use over the years with its attendant risk on a wide variety of wildlife [6]. Many of the ecological habitats have been lost to agricultural activities leading to animals' destruction by disaster and many more have been killed by poachers and local hunters. Many animal species are thus being endangered while some are extinct [2]. Uncontrolled legal and illegal hunting is putting a strain on the remaining wildlife populations [18]. Increased population pressure is among the most important indirect causes of loss of wildlife, and biodiversity in tropical rain forest [1,3]. If there is no alternative income generating sources, and where there is open access to land with little restriction to land leases, there is bound to be intense hunting, indiscriminate logging, fuel wood gathering, and shifting cultivation. This, in turn, leads to deforestation, habitat loss, wildlife scarcity, loss of biodiversity and erosion.

A good percentage of the forest cover of the Ethiope ecoregion has been lost. The remaining forest is heavily degraded and exploited. Loss of forest alone could extirpate most mammalian populations. From the interviews we conducted with the local hunters in the area there appears to be a drastic reduction in the number of mammals killed on a weekly basis. Happold [4] also reported the decline of mammalian species during the survey of mammals on the eastern boundary of the River Niger. Webala et al. [19] opined that habitat structural complexity is paramount in the conservation of small mammals in the drylands of north eastern Kenya. The local hunters also reported the sighting of some rare animal species such as the lesser bush baby, Galagoides domidovii, Bosman's potto, Perodicticus potto in the Ethiope ecoregion and that the West African Manatee, Manatus senegalensis is present within the River Ethiope. Actually some few years back a hunter caught and killed one of the manatee which was distributed as meat to the community.

Rodents such as the Porcupine and Cane rats and also the Gazelles, Duikers and the Civet-mongoose groups constitute the largest family of mammals, [20]. Some mammal species that thrive in the forest farmlands are sold for exorbitant prices; a greater cane rat sells for at least three thousand, five hundred Naira $(3,500)$.

There have also been reports on monkey thriving in Ethiope ecoregion, this was ascertained during a field study in Obiaruku (survey block I) when we sighted a monkey on a high branch with the aid of our binoculars, but could not specifically identify it as a result of its very high sensitivity and deficiency of data. As such, we refer to such data as oral evidence. All these, serve as an indication that hunting and agricultural activities have led to the decrease in diversity and abundance of large and small mammals.

Hunting of mammal species is ongoing at an unsustainable level, because bush meat is considered to taste good by people and can generate revenue to sustain their living. Pressures imposed on the animals and their habitat by villagers as they continue to cut trees for firewood, timber and to clear land for agriculture, building of houses and other infrastructural development, most animals that were once common in this area are either low in densities or extinct.

In most tropical forest rural areas and also in this Eastern Ethiope ecoregion, protein requirement of the local communities are either partly or almost entirely provided by the wild animals including birds, fish and mammals. Hunting is rather commercial other than subsistence sustainability. Clearly, use of wildlife as the sole source of protein in this area is unsustainable particularly when coupled with commercial hunting.

Despite the effect of hunting and habitat destruction, some mammalian species, have managed to adapt themselves to fragmented habitat and even to some are as completely transformed by human activities to farm areas and a considerable portion of their diet comprise of agricultural products e.g. the Grasscutter, Thryonomys Swinderianus.

The most common mammalian fauna in the area were the order Rodentia followed by Artiodactyla, Chiroptera and Carnivora. Insectivora, Primate and Pholidota occur in tiny violated populations subjected to local extinction. It is well known that the Order 
Citation: $\quad$ Arimoro FO, Kaine EA, Krumale BO, Obiegba S (2014) Ecological Observations, Preliminary Checklist and Conservation of Mammals Occurring Within the Eastern Boundaries of Ethiope River, Niger Delta Area of Nigeria. J Biodivers Biopros Dev 1: 104. doi:10.4172/ 2376-0214.1000104

Page 9 of 10

Artiodactyla are also reduced compared to the Order Rodentia, due to high market demand most especially of the Maxwell's duiker Cephalophus maxwelli and the Bushbuck, Tragelaphus scriptus which serve as a major revenue source to the local hunters and middlemen. This area clearly supports majority of small mammals and little large mammals.

The number of hunters and trappers operating within the area add up to Eighty six. Twenty eight in survey block I (Obiaruku), Thirty two in survey block II (Abraka) and Twenty six in survey block III(Eku). Out of these, a total of fifty two hunters use only guns, another ten use only traps and twenty of them use both guns and traps combined. There is a hunter's association in each survey block ( local communities), though their ethics in game hunting do not implement any conservation measures, hunters that use guns as a capital conservation measure do not shoot animals that could not be measured above the price of their bullet.

There is no belief against hunting or eating of any kind of mammal species, apart from the common orange-headed squirrel, Funisciurus olivae (Obokare) in Abraka survey block II attributed to saving the prince of Benin who founded Abraka. There are usually no sacred groves around, except for some protected shrines in Obiaruku and Otorho in Abraka (survey block I \& II).

There are two types of hunting that are predominant in this area. The night hunting which goes together with the hunter's lamp, usually powered by carbide. They also go together with their hunting dogs. The hunters' lamp is used in the night to search for reflection of most nocturnal mammals that have reflecting eye balls such as the African civet, Viverra civetta. There is also the day hunting, equipped with guns, dogs and co-operative hunting. The latter which has lately been prohibited by local hunters association.

An average of 55-56 animals are killed in a week within the study area, about 5 animals per hunter on the average kill. The average may vary within the year as there are seasonal variations in relative catch. It was also been noted that the catch may increase up to 70-90 during the dry season as a result of bush burning and food scarcity. Mr. Chukwuneku a local hunter in Obiaruku (survey block II) related to us that the Grasscutter, Thryonomys swinderianus, the Maxwell's duiker Cephalophus maxwelli, and the Giant rat Cricetomys gambianus are the most dominantly caught mammals within their survey block. This was also confirmed by Mr. Lawrence Edah a retired hunter in Abraka (survey block II) that the aforementioned mammals were also the dominant catch in this area.

In the bush meat market and also from the local pepper soup joints operating within the area, it was evident that the popular Grasscutter, Thryonomys swinderianus is in great demand by the patronizing customers. As such most selfish and pressured hunters have derived a drastic means of hunting by using chemicals mixed with human urine in cups which are placed at strategic locations. When these mammals are attracted to the drink from it, they eventually die in numbers hours after the poisoning. This type of hunting has resulted in an unsustained population of the Grasscutter that the local hunters association have put out jurisdictions towards this effect.

Species that are currently dominant and abundant in this region include; the Grasscutter, Thyronomys swinderianus, Maxwell's duiker, Cephalophus maxwelli, Giant rat, Cricetomys gambianus, Bushtailed Porcupine Atherurus africanus, Ground squirrel, Xerus erythropus, Cusimanse mongoose, Crossarchus obscurus, Bushbuck, Tragelaphus scriptus and the Franquets fruit bat, Epomops franqueti e.t.c.
The rare species in this area include; the Lesser bush-baby, Galagoides demidovii, the Forest genet Genetta poensis, the African civet, Viverra civetta the White bellied pangolin, Manis tricuspis, Bosman's potto, Perodicticus potto e.t.c. Trapping and hunting have led to a decline in the number of duiker Cephalophus sp.

The maxwell's duiker are densely populated mammal group within the study area, the present threat to them however is the gradual loss of their habitat due to uncontrolled farming, hunting and logging for timber and fuel wood.

The hunters also provided information on the animals they came across during hunting expedition especially on their feeding site, behaviour and little on their local ecology. Though there are still some untouched section of this area that are still thick, high levels of deforestation and indiscriminate hunting rates within the area are having a negative effect and are threatening to edge out existing wildlife populations. Given this orientation the most common approach has been the application of laws designed to prevent all exploitation of wildlife within these areas where animals and their habitats are in jeopardy, this approach is often the only practical first step towards long-term sustained conservation and management.

An efficient conservation means would be preservation and continued protection of wildlife species in the Ethiope ecoregion by efforts of communal forest authorities and traditional restrictions such as taboos to check the over-exploitation of wildlife species.

Most importantly and necessary is education of the local community about wildlife and its benefits for posterity.

\section{Conservation Recommendation}

The problem of overpopulation especially in communities around the eastern block of the Ethiope River depends largely on the rural agrarian economy revolving around forest products. There is thus an urgent need to evolve a management and legal strategy that will limit settlements in and around the Forest. Furthermore, the involvement of local communities in the management system of Forest has to be further developed. The management must evolve an institutional and legal framework for community participation in the decision-making process concerning management principles and practices that will enhance forest conservation and resource utilization. Community participation must be developed sustainably.

Furthermore there is a need to develop a sustainable silvicultural programme to restock and replenish the Forest, which has been depleted of some of its rare woody plants through illegal and indiscriminate logging. Agroforestry farming system should also be encouraged among the peripheral communities, as this system will enhance soil fertility and maintain the tropical rain forest mosaic. A thorough inventory of the wildlife of the Forest must be carried out. Wildlife management must be based on detailed knowledge of varieties of species, their total populations, sex ratio and other population characteristics upon which viable and sustainable game cropping depends. It is important also that game cropping be systematic and organized for optimum sustainable yield of bushmeat. There must be strict hunting laws and a massive campaign in the environs of the Ethiope River ecotone to increase public awareness of the importance of wildlife and forest conservation. There must also be a programme of research into management practices for sustainable economic benefits to Delta State Government, the Niger Delta people and the rural communities. 
Citation: $\quad$ Arimoro FO, Kaine EA, Krumale BO, Obiegba S (2014) Ecological Observations, Preliminary Checklist and Conservation of Mammals Occurring Within the Eastern Boundaries of Ethiope River, Niger Delta Area of Nigeria. J Biodivers Biopros Dev 1: 104. doi:10.4172/ 2376-0214.1000104

Page 10 of 10

In order to preserve the existing mammalian population and to prevent threatened species from going to extinction, it is recommended that Government and other conservation bodies should implement conservation measures (laws and policies). These will reduce greatly illegal, unregulated and unmanaged hunting, bush burning and deforestation. Government should also generate income activities for the local people within the research area that could replace exploitation of the forest and ensure long-term survival of mammals and safeguard the rainforest. Also comprehensive ecological monitoring programs of wildlife species and improved management and protection of rainforests should be priorities. Local communities and hunters should be educated on the importance of conservation. If this can be accomplished, the mammals will be among the many beneficiaries.

\section{References}

1. Egwali EC, king RP, Eniang EA, Obot EA (2005) Discovery of a new population of the Sclater's guenon, Cercopithecus sclateri in the Niger Delta wetlands, Nigeria. Living Systems \& Sustainable Development $2: 1$ -7 .

2. Baker LR, Olubode OS (2008) Correlates with the distribution and abundance of endangered Sclater's monkey (Cercopithecus sclateri) in southern Nigeria. African Journal of Ecology 46: 365. 373.

3. Okorie PU, Ekechukwu K (2013) Tragedy of commons: stress and survival of the Lagwa (Nigeria) Monkeys. International Journal of Science Environment $2: 1099-1106$.

4. Happold DCD (1987) The Mammals of Nigeria. Oxford University Press Oxford.

5. Angelici FM, Grimod I Politano E (1999) Mammals of the Eastern Niger Delta (Rivers and Bayelsa States, Nigeria): An environment affected by a gas pipeline. Folia Zool 48: 249-264.

6. Angelici, FM, Egbide B Akani GC (2001). Some new mammal records from the rainforests of southern- eastern, Nigeria. Hystrix It.J.Mamm. $12: 37-43$.

7. Baker LR, Tanimola AA, Olubode OS, Garshelis DL (2009) Distribution and abundance of sacred monkeys in Igboland, southern Nigeria. Am J Primatol 71: 574-586.
8. Bowen-Jones E, Pendry S (1999) The threat to primates and other Mammals from the bushmeat Trade in Africa and how this threat could be diminished. Oryx 33: 233-246.

9. Odoemena CSI, Egwali EC (2006) Fundamentals of Conservation and Development of Natural Resources in Nigeria. Uwana Graphics Press 27 Umoren Street, Uyo-Akwa-bom State.

10. Oates JF Anadu EL Godsby L Were JL (1992) Sclater's Guenon-A Rare Nigerian Monkey Threatened by Deforestation. National Geographic Research and Exploration 8: 476-491.

11. Happold DCD (1995) The interactions between humans and mammals in Africa in relation to conservation:a review. Biodiversity and Conservation 4: 395-414.

12. Ikomi RB, Arimoro FO (2014) Effects of Recreational activities on the Littoral Macroinvertebrates of Ethiope River, Niger Delta, Nigeria. Journal of Aquatic Sciences 29 : 153-168.

13. Booth AH (1960) Small mammals of West Africa. Longmans Green and Co., Ltd., London. 68.

14. De Blase AF, Martin RE (1981) A manual of mammalogy with keys to the families of the World. Wm. C. Brown Publishers, Dubuque, Iowa, xii + 436.

15. Theodore H, Helmut D (1986) A Field guide to the Mammals of Africa including Madagascar. South China Printing Co, Hong Kong.

16. Ludwig JA, Reynolds JF (1988) Statistical Ecology, a Primer on Methods and Computing. Wiley/Interscience, Wiley, New York. 337.

17. IUCN Species Survival Commission (2000) 2,000 IUCN Red List of Threatened Species. Cambridge UK. 52-64.

18. Oates JF (1989) A survey of primates and other forest wildlife in Anambra, Imo and Rivers States, Nigeria. A report to the NatFoundation, the Nigerian Federal Dept of Forestry, and the Governments of Anambra, Imo and Rivers States. Pp ii+40. mimeo.

19. Webala PW, Carugati C, Fasola M (2010) Diversity in small mammals from eastern Lake Turkana, Kenya. Tropical Zoology 23:9-20.

20. Decher J (1997) Conservation, Small Mammals and the future of Sacred Grooves in West Conservation, Small Mammals and the future of Sacred Grooves in West Africa. Biodiversity and Conservation 6: 1007-1026. 